\title{
PERANAN INTRINSIC AND EXTRINSIC MOTIVATION DALAM MENINGKATKAN PRESTASI OLAHRAGA
}

\author{
Ardyansyah Arief Budi Utomo \\ Titin Kuntum Mandalawati \\ ardyansyah_arief_a7x@rocketmail.com \\ mandalawatititin@gmail.com \\ Universitas PGRI Madiun
}

\begin{abstract}
Abstrak
Dalam dunia keolahragaan, banyak masalah yang harus dipecahkan dalam hal peningkatan prestasi. Bukan hanya dari skill pelatih maupun atlet saja, namun diluar itu ada masalah-masalah yang berhubungan dengan psikologis yang berhubungan langsung dengan keberlangsungan pertandingan olahraga yang notabene sangat berpengaruh pada prestasi olahraga. Faktor psikologis yang dapat membantu atau menunjang prestasi atlet salah satunya ialah motivasi. Peranan motivasi dari dalam atlet (intrinsic) dan dari luar atlet (extrinsic) perlu dibangkitkan, dirangsang, serta diasah sehingga atlet mampu menghadapi situasi-situasi pertandingan dalam lapangan yang berhubungan dengan wilayah psikis atlet. Dengan membangkitkan, merangsang, serta mengasah motivasi atlet, diharapkan mampu memperbaiki atau bahkan meningkatkan prestasi atlet dalam tingkat nasional bahkan internasional.
\end{abstract}

Kata Kunci: Intrinsic Motivation, Extrinsic Motivation, Prestasi Olahraga.

\section{A. PENDAHULUAN}

Dalam kegiatan olahraga utamanya olahraga prestasi yang mana setiap atlet dituntut untuk meraih prestasi yang lebih bagus dari sebelumnya, atau dituntut untuk lebih bagus dari prestasi lawan mainnya. Sebagai contoh, prestasi limit atlet A dalam lari sprint 100 meter adalah 12.70 detik, jika atlet A ingin memperbaiki prestasinya sendiri maka dia harus berlatih dengan keras agar prestasi lari sprintnya lebih cepat dari sebelumnya. Selain itu, atlet A juga harus berkompetisi di pertandingan dengan lawan mainnya, jika atlet $\mathrm{A}$ ingin meraih prestasi yang lebih bagus, maka limit lari 100 meter atlet A harus lebih baik dari atlet $\mathrm{B}, \mathrm{C}, \mathrm{D}$, dan seterusnya.

Langkah-langkah untuk meraih prestasi tidak semudah membalikkan telapak tangan, perlu semangat, latihan yang rutin, serta kerja keras untuk meraih prestasi yang diinginkan. Selain faktor latihan yang notabene berada dalam wilayah fisik, maka faktor psikologis dari tiap-tiap atlet pun perlu dirangsang, dilatih, dan dikembangkan. Salah satu faktor psikologi tersebut adalah motivasi. 
Motivasi merupakan salah satu konsep psikologi yang paling banyak digunakan dalam olahraga. Faktanya, motivasi memang menjadi sesuatu yang sangat urgent. Robert N Singer, seorang tokoh psikologi olahraga pernah membuat formula yaitu Performance $=$ Learning + Motivation (Maksum, 2008: 29)

Dari formula di atas, Singer ingin menunjukkan betapa pentingnya motivasi dalam olahraga. Prestasi akan optimal apabila ada proses latihan dan didukung oleh motivasi yangkuat. Artinya, berlatih saja tidak cukup tanpa adanya arah dan intensitas usaha yang optimal. Dilihat dari sumbernya, ada dua jenis motivasi, yaitu motivasi intrinsik (intrinsic motivation) dan motivasi ekstrinsik (extrinsic motivation). Motivasi intrinsik adalah motivasi yang berasal dari dalam diri individu yang bersangkutan. Sedangkan motivasi ekstrinsik adalah motivasi yang berasal dari luar individu (Maksum, 2008: 33).

\section{B. PEMBAHASAN}

\section{Hakikat Motivasi}

Kata motif seringkali diartikan dengan istilah dorongan. Dorongan atau tenaga tersebut merupakan gerak jiwa dan jasmani untuk berbuat, jadi motif tersebut merupakan suatu driving force yang menggerakkan manusia untuk bertingkah laku, dan didalam perbuatannya itu mempunyai tujuan tertentu. Menurut Nawawi (dalam Maksum 2007: 29), motivasi diartikan sebagai suatu keadaan yang mendorong atau menjadi sebab seseorang melakukan sesuatu perbuatan atau kegiatan yang berlangsung secara sadar.

Sementara itu (dalam Maksum, 2007: 34), menyebutkan bahwa motivasi adalah dorongan seseorang untuk meraih kesuksesan. Kesuksesan bukanlah suatu yang instan, tetapi melalui proses yang panjang. Dalam proses tersebut sangat boleh jadi banyak tantangan, ketidaknyamanan, dan bahkan kegagalan. Mantan Perdana Menteri Inggris, Winston Churchill mengatakan: "succes is ability to go from failure to failure without losing your enthusiasm." Orang yang memiliki kecenderungan kuat untuk meraih selalu berusaha bekerja keras, berusaha mengatasi masalah, berkomitmen, dan berusaha lebih baik dibandingkan dengan yang lain.

Dalam sumber lain mengatakan bahwa seseorang harus meyakini bahwa pendorong atau motivasi itu dapat membuat dia untuk merealisasikan harapannya (Weiner, 1995: 548-573). Dalam hal ini, keyakinan seseorang 
terhadap sebuah motivasi sangatlah penting guna mewujudkan hasil yang diinginkan.

\section{Teori Motivasi}

Dalam motivasi, terdapat pula teori-teori motivasi yang dikemukakan oleh para ahli, teori-teori motivasi itu akan disebutkan sebagai berikut:

\section{a. Teori Motivasi F.W Taylor}

Pendekatan pada teori ini memusatkan perhatian membuat pekerjaan seefektif mungkin dengan merampingkan metode kerja, pembagian tenaga kerja, dan penilaian pekerjaan. Pekerjaan dibagi dalam berbagai komponen, diukur dengan menggunakan teknik-teknik penelitian pekerjaan dan diberi imbalan sesuai dengan produktivitas (Uno, 2014: 39). Pada pendekatan ini menganggap uang (insentif) sebagai motivasi utama.

\section{b. Teori Motivasi Hierarki Kebutuhan Maslow}

Setiap kali membicarakan tentang motivasi, hierarki kebutuhan Maslow pasti disebut-sebut. Hierarki itu didasarkan pada anggapan bahwa, pada waktu orang telah memuaskan satu tingkat kebutuhan tertentu, maka mereka ingin bergeser ke tingkat yang lebih tinggi (Uno, 2013: 40).

Maslow mengemukakan lima tingkat kebutuhan seperti terlihat pada gambar 2.1 berikut ini:

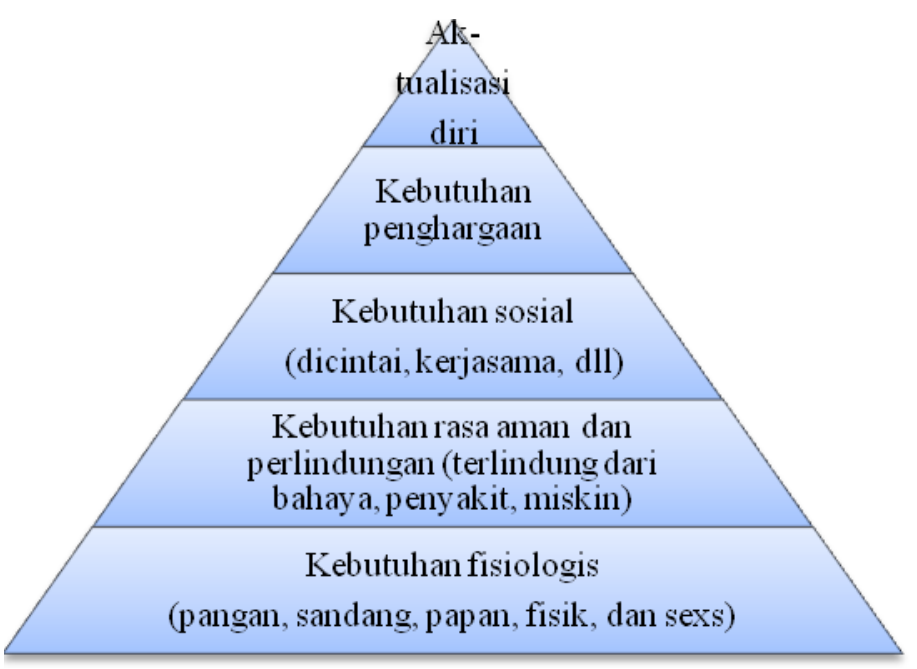

Gambar 2.1 Teori Kebutuhan Maslow (Uno, 2013: 40). 
1) Kebutuhan Fisiologis

Kebutuhan yang harus dipuaskan untuk tetap dapat hidup, termasuk makanan, perumahan, pakaian, udara untuk bernapas, dan sebagainya.

2) Kebutuhan Akan Rasa Aman

Ketika kebutuhan fisiologis seseorang telah dipuaskan, perhatian dapat diarahkan kepada kebutuhan akan keselamatan. Keselamatan itu termasuk merasa aman dari setiap jenis ancaman fisik atau kehilangan, serta merasa terjamin.

3) Kebutuhan Sosial

Ketika seseorang telah memuaskan kebutuhan fisiologis dan rasa aman, kepentingan berikutnya adalah hubungan antar manusia atau kebutuhan sosial. Cinta kasih dan kasih sayang yang diperlukan pada tingkat ini mungkin disadari melalui hubungan-hubungan antar pribadi yang mendalam, tetapi juga dicerminkan dalam kebutuhan untuk menjadi bagian dari berbagai kelompok sosial.

4) Kebutuhan Penghargaan

Percaya diri dan harga diri maupun kebutuhan akan pengakuan dari orang lain.

5) Kebutuhan Aktualisasi Diri

Kebutuhan ini ditempatkan paling atas pada hierarki kebutuhan Maslow dan berkaitan dengan pemenuhan diri. Ketika semua kebutuhan lain sudah dipuaskan, seseorang ingin mencapai secara penuh potensinya yakni dengan mengembangkan bakat dengan usaha mencapai hasil dalam bidangnya.

\section{c. Teori Motivasi X dan Y McGregor}

Teori ini mengemukakan 2 pandangan manusia yaitu teori $\mathrm{X}$ (negatif) dan teori $\mathrm{Y}$ (positif).

1) Teori $X$

Menurut teori $\mathrm{X}$, manajer memandang para pekerja sebagai pemalas yang tidak dapat diperbaiki, oleh karena itu mereka cenderung menggunakan pendekatan yang bersifat hukuman.

2)

\section{Teori Y}

Kontras dengan teori $\mathrm{X}$, menurut teori $\mathrm{Y}$, manajer memandang bahwa orang-orang pada dasarnya cenderung untuk bekerja keras dan melakukan pekerjaan dengan baik. Atasan yang memotivasi bawahannya akan tampak dengan jelas dapat memotivasi bawahannya (Uno, 2013: 45). 


\section{d. Teori Motivasi Prestasi McClelland}

Menurut teori ini, motivasi manusia terdiri dari 3 kebutuhan yang dominan, yakni kebutuhan berprestasi (need for achievement), kebutuhan kekuasaan (need for power), dan kebutuhan afiliasi (need for affiliation). Pernyataan McClelland tersebut tertuang dalam (Moore, dkk, 2010: 2234). McClelland menekankan pentingnya kebutuhan berprestasi. Individu yang memiliki motivasi yang kuat mempunyai kecenderungan tertentu. Menurut McCleland (1961) dan Atkinson (1974) (dalam Maksum, 2007: 35 ), seseorang yang memiliki motivasi, menunjukkan ciri-ciri sebagai berikut:

1) Selalu berorientasi pada perbaikan kinerja.

2) Senang terhadap tugas yang menantang.

3) Gigih, tidak gampang menyerah.

4) Menyukai tanggung jawab pribadi.

5) Bertindak efisien.

6) Menyukai umpan balik atas pekerjaan yang dilakukan.

7) Mendapat kepuasan dari melakukan sesuatu yang lebih baik.

\section{e. Teori Self Determination}

Menurut Deci \& Ryan (2008), menyebutkan perbedaan yang paling menonjol didalam self determination theory antara motivasi mandiri (motivasi otonom) dan motivasi yang dikendalikan. Motivasi otonom terdiri dari motivasi intrinsik dan ekstrinsik, dimana orang telah mengintegrasikannya kedalam diri mereka. Sementara itu, motivasi yang dikendalikan, terdiri dari regulasi atau pengaturan eksternal, dimana perilaku seseorang dikendalikan oleh hadiah atau hukuman (Deci \& Ryan, 2008: 182-185). Dilihat dari sumbernya, ada dua jenis motivasi, yaitu:

1) Motivasi Intrinsik

Motivasi intrinsik adalah motivasi yang muncul dari individu itu sendiri. Jika siswa termotivasi secara intrinsik, ia akan melaksanakan tugas dengan perilaku tanpa mengharapkan suatu pujian atau imbalan dari luar dirinya. Sebagai contoh jika seorang atlet berlatih cabang olahraga basket dan mendapatkan kesenangan dan kenikmatan dari latihan tersebut, maka dapat dikatakan bahwa atlet tersebut termotivasi secara intrinsik (Maksum, 2007: 33). 
2) Motivasi Ekstrinsik

Motivasi ekstrinsik adalah motivasi yang berasal dari luar individu yang bersangkutan. Tindakan yang dilakukan oleh orang yang memiliki motivasi ini cenderung didasari oleh keinginan untuk memperoleh hadiah (reward) dari lingkungan. Seperti uang, piala, piagam, atau penghargaan lainnya (Maksum, 2007: 33).

\section{Pendekatan Dalam Memahami Motivasi}

Sementara itu (dalam Maksum, 2007: 39), disebutkan pendekatanpendekatan dalam memahami motivasi yaitu:

a. Motivasi sebagai sifat yang dimiliki seseorang (trait centered).

Menurut pendekatan ini, motivasi pada dasarnya merupakan fungsi dari karakteristik individu, yakni kepribadian, kebutuhan, minat, dan tujuan dari individu yang bersangkutan.

b. Motivasi sebagai bentukan dari lingkungan (situation centered).

Menurut pendekatan ini, motivasi seseorang pada dasarnya ditentukan oleh situasi dimana orang tersebut berada.

c. Motivasi sebagai interaksi antara sifat seseorang dan pengaruh situasi (trait situation).

Menurut pendekatan ini, motivasi pada dasarnya merupakan interaksi antara karakteristik yang dimiliki individu, dan situasi dimana individu tersebut berada (Maksum, 2007: 39).

\section{Indikator Motivasi}

Menurut Ardyansyah (2015: 54), indikator motivasi intrinsik dan ekstrinsik dapat diuraikan dalam tabel berikut:

Tabel 2.1 Indikator Motivasi

\begin{tabular}{|l|l|l|}
\hline Variabel & \multicolumn{1}{|c|}{ Dimensi } & \multicolumn{1}{|c|}{ Indikator } \\
\hline \multirow{2}{*}{ Motivasi } & Intrinsik & $\begin{array}{l}\text { a. Kesenangan } \\
\text { b. Minat } \\
\text { c. Pengetahuan } \\
\text { d. Kebutuhan }\end{array}$ \\
\cline { 2 - 3 } & \multirow{2}{*}{ Ekstrinsik } & $\begin{array}{l}\text { a. Guru } \\
\text { b. Teman } \\
\text { c. Sarana } \\
\text { d. Orang tua }\end{array}$ \\
\hline
\end{tabular}




\section{Cara Meningkatkan Motivasi}

Pada konteks masalah motivasi, tentu sangat diharapkan solusisolusi yang dapat memecahkan masalah tersebut, berikut penjelasan caracara meningkatkan motivasi menurut Maksum (2007:40).

a. Memahami Faktor Pribadi Seseorang

Pahami faktor pribadi seseorang dan situasi yang ada. Jangan mengambil langkah apapun sebelum memahami apa yang menyebabkan individu kurang termotivasi. Faktor diri individu atau lingkungan. Jika faktornya dari individu, maka perlu adanya pendekatan pribadi, tetapi jika faktornya lingkungan, maka perlu dilakukan modifikasi lingkungan yang lebih menarik.

b.

\section{Seseorang Memiliki Lebih Dari Satu Motif}

a. Pahami mengapa seseorang berpartisipasi dalam aktivitas fisik.

b. Orang memiliki lebih dari satu alasan untuk berpartisipasi.

c. Motif dapat berubah setiap waktu.

\section{c. Merekayasa Lingkungan}

Merekayasa lingkungan adalah salah satu cara untuk meningkatkan motivasi

a. Kompetisi atau rekreasi.

b. Memberikan berbagai kesempatan.

c. Sesuaikan karakteristik individu dalam kelompok.

\section{d. Pemberian Reward.}

Pemberian reward sudah sangat umum dan peluang keberhasilannya dalam meningkatkan motivasi sangat besar sekali.

\section{e. Pemimpin Mempengaruhi Motivasi.}

Apa yang dilakukan seorang pemimpin, apakah itu pelatih, orangtua, guru, atau pembina dapat mempengaruhi motivasi individu yang dipimpin. Misalnya sikap-sikap yang diskriminatif, kesempatan yang tidak optimal, kurang dapat mendengar dan memahami individu. Semua itu dapat menjadi penyebab individu kehilangan motivasi.

\section{f. Modifikasi Tingkah Laku}

Menggunakan modifikasi tingkah laku untuk merubah motif yang negatif. Adakalanya individu memiliki motif tertentu yang negatif untuk melaksanakan tujuannya. Misalnya suka melakukan kekerasan saat bertanding, tidak sportif, dan sering melanggar peraturan. Dalam kondisi yang demikian, individu yang bersangkutan perlu dimodifikasi tingkah lakunya. 


\section{KESIMPULAN}

Dalam meningkatkan prestasi bagi atlet, maka pemberian motivasi perlu dilakukan oleh pelatih atau official dari klub bersangkutan. Untuk intrinsic motivation atau motivasi intrinsik atlet, maka atlet diharapkan mempunyai kesenangan dan keinginan yang muncul dari dirinya sendiri mengenai cabang olahraga yang dia tekuni, karena hal itu berhubungan langsung dengan nyaman atau tidaknya dia dalam menjalani cabang olahraga tersebut yang juga akan mempengaruhi prestasi bagi atlet tersebut.

Sedangkan untuk pemberian extrinsic motivation atau motivasi ekstrinsik dapat dilakukan oleh pelatih atau official klub yang bersangkutan. Mulai dari pemberian reward (penghargaan) berupa pujian, sanjungan, tepuk tangan sampai pada reward berupa uang. Pemberian reward atau penghargaan berupa verbal (pujian atau sanjungan) adalah cara pemberian motivasi ekstrinsik yang sangat mudah sekali dilakukan dan tidak membutuhkan biaya. Hal itu dapat dilakukan oleh pelatih atau pihak yang bersangkutan kepada atlet pada saat dilakukannya latihan rutin.

Pemberian reward berupa verbal untuk meningkatkan motivasi atlet dinilai kurang efektif tanpa adanya pemberian reward berupa uang. Pelatih bisa memotivasi atlet bagi siapa saja atletnya yang mampu meraih prestasi tertentu (limit waktu atau target tertentu). Bahkan pada klub-klub profesional, mereka menyediakan beberapa sarana dan prasarana yang memadai bagi atlet seperti kelengkapan sepatu, baju, tas, jaket, makan, tempat tinggal bagi atlet dan pemusatan latihan (training center). Semua cara tersebut dilakukan pelatih dan pihak official klub tertentu untuk meningkatkan prestasi atlet melalui motivasi.

\section{DAFTAR PUSTAKA}

Arief, Ardyansyah. (2015). Pengaruh Pemberian Reward Terhadap Motivasi Belajar Siswa Dalam Pembelajaran Penjasorkes. Surabaya. Unesa.

Deci, L.E., \& Ryan, M.R. (2008). "Self determination theory: A macrotheory of human motivation, development, and health". Canadian psychology. Vol.49 No.3, pp.182-185).

Maksum, Ali. (2007). Psikologi Olahraga. Surabaya: Unesa University Press.

Maksum, Ali. (2011). Psikologi olahraga teori dan aplikasi. Surabaya: Unesa University Press. 
Uno, Hamzah. (2014). Teori motivasi dan pengukurannya. Jakarta: Bumi Perkasa.

Weiner, B. (1995). "An attributional Theory of achievement motivation and emotion". Psychological review. Vol.92 No.4, pp. 548-573. 